\title{
THE EFFECT OF DIFFERENT POSITION OF GRAPE CLUSTERS ON THE BEARING SHOOT ON PRODUCTION RESULTS OF CABERNET SAUVIGNON CLONES
}

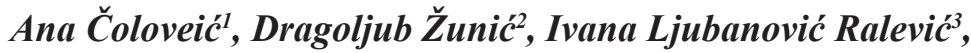 \\ Branka Kalanović Bulatovićc ${ }^{4}$, Mirjana Lukač Bulatovićc ${ }^{5}$
}

\begin{abstract}
Summary
In this paper the differences were examined between clones of Cabernet sauvignon (clones $I S V-F-V 5, I S V-F-V 6$ and R5), i.e. the difference between uvological properties of grape clusters and grape berries, based on the different positions on the bearing shoot. Tests were conducted at the experimental field of the Faculty of Agriculture "Radmilovac." Standard ampelographic methods were used in numerous analyses of grape yield, as well as uvological properties of clones. All data were statistically analyzed and processed by the method of two-factor analysis of variance with repeated measuring of one factor (height) and Tukey HSD test. Analysis of variance showed no significant differences between clones. The best results were achieved with grape clusters positioned in the base of bearing shoot. The first positioned grape clusters on the bearing shoot had the highest share in the total grape yield, the highest amount of sugar, and the highest positioned grape clusters had higher content of total acids. The differences determined between examined clones were in regard to productivity and quality of grapes which reflected also on production value.
\end{abstract}

Key words: Cabernet sauvignon, clones, positions on the bearing shoot, uvological properties of grapes, production results.

JEL: $J 43$

1 Ana M. Čoloveić, B.Sc., University of Belgrade, Faculty of Agriculture, Nemanjina Street no. 6, 11080 Belgrade, Serbia, Phone:+381 64 2548993, E-mail: coloveic@gmail.com

2 Dragoljub M. Žunić, Ph.D., Full professor, University of Belgrade, Faculty of Agriculture, Nemanjina Street no. 6, 11080 Belgrade, Serbia, Phone: +381 65 5222434, E-mail: dragoljubzunic@gmail.com

3 Ivana I. Ljubanović Ralević, Ph.D., Full professor, University of Belgrade, Faculty of Agriculture, Nemanjina 6, 11080 Belgrade, Serbia, Phone: +381 64 1447496, E-mail: iralevic@agrif.bg.ac.rs

4 Branka M. Kalanović Bulatović, Ph.D., Associate professor, University of Belgrade, Faculty of Agriculture, Nemanjina Street no. 6, 11080 Belgrade, Serbia, Phone: +381 642743330 , E-mail: brankal@agrif.bg.ac.rs

5 Mirjana Ž. Lukač Bulatović, Ph.D., Assistant professor, University of Novi Sad, Faculty of Agriculture, Trg Dositeja Obradovića 8, 21000 Novi Sad, Serbia, Phone: +381 638929721 , E-mail: imirjana@polj.uns.ac.rs

EP 2014 (61) 1 (17-24) 


\section{Introduction}

Cabernet sauvignon is one of the best and most common varieties in the world. The interest for it in Serbia is very large because it is intended for the production of quality red wines. It is a very old variety originating from France, prone to many variations and mutations. Prolonged vegetative reproduction of this species contributes to its degradation in terms of positive qualities. For these reasons, most research centers in France, Italy, Hungary and other countries, conduct clonal selection (Avramov et al., 2001). The aim of clonal selection is to purify a variety in order to obtain clones that retain all the features of the original plant species, and some clones even exceed the variety population in certain features, especially in terms of increased resistance to downy mildew, powdery mildew and gray rot (Rühl et al., 2004). Cabernet sauvignon is the most commonly grown variety in conditions of frequent rainfall and high relative air humidity, due to greater resistance to gray mold of grapes (Nakalamić et al., 2009). In such conditions, it accumulates $20-24 \%$ of sugars and 5.5 to $8.0 \mathrm{~g} / 1$ of total acids, with the average yield, and wines contain $12-24 \%$ alcohol and $5-7 \mathrm{~g} / 1$ of total acids. The wine is very smooth, of harmonious taste/aroma and a characteristic odor resembling a forest violet (Žunić, 2009). Hence, this variety is considered one of the highest quality wine varieties, and given the resistance to low temperatures it can be successfully grown in the continental conditions.

\section{Material and Methods}

The tests were conducted at the experimental field of the Faculty of Agriculture "Radmilovac." Experimental vineyard was built in 2003, and it includes growing grapes in rows with formed Double Guyot training system. Spacing is $3 \mathrm{~m}$ between rows and $1 \mathrm{~m}$ between vines in the row. The direction of rows is North-East- South-West. The tests were performed using standard ampelo-technical methods in laboratory and field conditions. The tested clones were planted on the same plot. They were grafted on different basis of clones SO4 (clone ISV-F-V5 grafted on SO4 clone 310P, ISV-F-V6 grafted on SO4 clone 102 and R5 grafted on SO4 clone 74). Ten (10) experimental vines of each clone were selected randomly. The indicators of the growth potential of clones were determined: the number of productive bearing shoots and the number of grape clusters per vine. At the time of harvest, the number of grape clusters per vine was determined, also, yield per vine and average grape cluster mass. Uvological properties were determined by standard methods, the structure of grape cluster and grape berry was determined, and the quality of grape must as one of the technological characteristics. Mechanical composition of grape cluster and berry was determined according to the method by Prostoserdov (1946). Sugar content of grape must was analyzed using the Oechsle tester - apparatus for measuring the density of grape must and total acid content was determined by method of titration using $\mathrm{n} / 4 \mathrm{NAOH}$ solution. To check the significance of differences between the clones and positions of grape clusters on the bearing shoot, the method of two-factor analysis of variance with repeated measures of one factor (height) and Tukey HSD test were applied. Based on the results obtained from the experiments, the calculation of the regular maintenance of vineyards was performed, which was the basis for making business decisions. Considering that investments in 
vineyards represent long-term investments that their character determines the degree of risk and uncertainty with a constant problem of providing the funds needed, the mathematical model is presented which should give an answer to the question of economically justified financial investment.

\section{Results and Discussion}

The results of the study of the yield capacity of ISV-F-V5, ISV-F-V6 and R5clones of Cabernet sauvignon variety are expressed as the number of productive shoots and the number of grape clusters of different positions on the bearing shoot (Table 1). In all tested clones the same tendency was revealed. Bearing/productive shoots usually had 1-2 grape clusters, while a smaller number of bearing/productive shoots had 3 clusters. Clone ISVF-V5 had the largest number of shoots (7.2), but the clone ISV-F-V6 had the largest number of clusters per vine (22.4). Clone ISV-F-V6 had the highest number of second and third grape clusters per bearing shoot.

Table 1. Average number of bearing/productive shoots and grape clusters per bearing shoot

\begin{tabular}{|c|c|c|c|c|c|}
\hline \multirow{2}{*}{ Clone } & \multirow{2}{*}{$\begin{array}{c}\text { Average number } \\
\text { of bearing shoots } \\
\text { per vine }\end{array}$} & \multicolumn{2}{|c|}{$\begin{array}{c}\text { Average number of grape clusters per } \\
\text { bearing shoot }\end{array}$} & \multirow{2}{*}{$\begin{array}{c}\text { Total grape clusters } \\
\text { per vine }\end{array}$} \\
\cline { 3 - 5 } & & first & $\begin{array}{c}\text { second } \\
\text { (base) }\end{array}$ & $\begin{array}{c}\text { third } \\
\text { (top) }\end{array}$ & \\
\hline ISV-F-V5 & 7.2 & 10.8 & 5.7 & 3.2 & 16.7 \\
\hline ISV-F-V6 & 6.7 & 12.0 & 6.7 & 3.7 & 22.4 \\
\hline R5 & 5.2 & 7.5 & 5.8 & 2.3 & 15.7 \\
\hline
\end{tabular}

The present investigation has confirmed the results of other authors stating that clone ISVF-V6 in different environmental, ecological conditions has a very good yield that exceeds the population of the variety (Golino et al., 2008). In regard to the average grape cluster mass, it was established that the R5 clone had higher mass of grape clusters in the base and middle of shoot compared to the other clones. Also, the third grape cluster (top) of this clone had the lowest weight (Table 2).

Table 2. Average mass of grape cluster

\begin{tabular}{|c|c|c|c|c|c|c|c|}
\hline \multirow{2}{*}{ Clone } & \multicolumn{3}{|c|}{$\begin{array}{c}\text { Average mass of grape } \\
\text { cluster (gr) }\end{array}$} & \multicolumn{3}{c|}{$\begin{array}{c}\text { Average yield of grape cluster } \\
\text { per vine (kg) }\end{array}$} & \multirow{2}{*}{ Total } \\
\cline { 2 - 7 } & base & middle & top & base & middle & top & \\
\hline ISV-F-V5 & $98.1^{\mathrm{a}}$ & $96.4^{\mathrm{a}}$ & $36.0^{\mathrm{b}}$ & 1.059 & 0.549 & 0.115 & 1.723 \\
\hline ISV-F-V6 & $100.5^{\mathrm{a}}$ & $85.9^{\mathrm{a}}$ & $42.2^{\mathrm{b}}$ & 1.184 & 0.575 & 0.156 & 1.915 \\
\hline R5 & $103.4^{\mathrm{a}}$ & $109.6^{\mathrm{a}}$ & $22.1^{\mathrm{b}}$ & 0.785 & 0.636 & 0.050 & 1.471 \\
\hline
\end{tabular}

${ }^{a-b}$ values marked with different letters in superscript are statistically highly significant.

The differences in yield per vine between the base and the top of all 10 tested vines were following: in clone ISV-F-V5-9.44 kg, ISV-F-V6-10.28 kg and $7.35 \mathrm{~kg}$ for R5. Slightly smaller differences were established between the middle and top: $4.34 \mathrm{~kg}$ for clone ISVF-V5, $4.19 \mathrm{~kg}$ for clone ISV-F-V6 and $5.86 \mathrm{~kg}$ for the R5 clone. 
According to the literature data (Milosavljević, 1998), (Cindrić et al., 2000) Cabernet sauvignon gape cluster mass is in the range of 60 to $130 \mathrm{~g}$. The data obtained in the experiment indicated that clones of this variety had quite even ampelo-graphic property such as cluster mass. There was a statistically significant difference in the mass of clusters depending on the position on the bearing shoot. There was no statistically significant difference between the mass of clusters that were positioned at the base and in the middle of the shoots. However, there was a statistically highly significant difference between the masses of clusters that were at the top of the shoot and mass of grape clusters that were located in the base and middle of the shoot.

The highest share in the yield of grapes in all three clones was recorded for the first clusters positioned on the bearing shoot, followed by clusters in the middle of the shoot with a $30 \%$ share, and at least clusters from the top of shoots with approx. 3-7\% share (Table 3). Grape clusters which are first and second in their position on the shoot bear in average of $94 \%$ of the mass of grapes. Considering this information, it is recommended that in the fertile years, the top (highest) grape clusters are thinned first, and then those that are in the middle of the bearing shoots. In this way, the yield is reduced as a part of the plan in order to improve the quality of grapes.

Table 3.Share of grape clusters of different position on the bearing shoot in total yield (\%)

\begin{tabular}{|c|c|c|c|}
\hline \multirow{2}{*}{ Clone } & \multicolumn{3}{|c|}{ Position of grape clusters on the bearing shoot } \\
\cline { 2 - 4 } & base & middle & top \\
\hline ISV-F-V5 & 61.44 & 31.86 & 6.68 \\
\hline ISV-F-V6 & 61.81 & 30.03 & 8.14 \\
\hline R5 & 53.37 & 43.17 & 3.45 \\
\hline
\end{tabular}

For manufacturers it is important to monitor production costs, calculate cost of one kilogram of grapes and find a way to maintain the vineyard profitable as long as possible, and that this does not affect the quality of grapes and wine (Table 4).

Table 4. Cost of regular maintenance of 1ha vineyard

\begin{tabular}{|l|c|c|c|}
\hline \multirow{2}{*}{ Description of cost } & \multicolumn{3}{|c|}{ Clone } \\
\cline { 2 - 4 } & ISV-F-V5 & ISV-F-V6 & R5 \\
\hline Protection preparations & 49,500 & 49,500 & 49,500 \\
\hline Labor & 56,000 & 56,000 & 56,000 \\
\hline Mechanization & 39,150 & 39,150 & 39,150 \\
\hline Harvest & 25,840 & 28,720 & 22,070 \\
\hline Total & 170,490 & 173,370 & 166,720 \\
\hline
\end{tabular}

Source: According authors' calculation.

The purchase price of grapes is $30.00 \mathrm{RSD}$. On the basis of the realized differences in total yield, expected costs and revenues it can be concluded that the growing of clones ISV-F-V6 is economically most profitable. 
When defining the investment model it is assumed that the money in the amount $\mathrm{N}$ to would be invested in improving production. Clones are alternatives for investment. Each option after $\mathrm{j}_{\mathrm{i}}$ year brings profit of $\mathrm{q} \%$ annually $(\mathrm{i}=1,2, \ldots ., \mathrm{m})$. Part of the money available that is not invested brings interest of $\mathrm{p} \%$ per year. Starting point is the assumption that the profit obtained from certain alternatives is used for further investment in the same alternatives. At the beginning of each year the investment structure should be determined that would provide maximum profit at the end of the year $\mathrm{k}$.

Thus defined, the problem can be described by the following mathematical model:

a) Variables

$\mathrm{X}_{\mathrm{it}}$ - the amount of money invested into the alternative $\mathrm{i}$ during the year $\mathrm{t}, \mathrm{i}=1,2, \ldots \mathrm{m}$; $\mathrm{t}=1,2, \ldots \mathrm{k}$

$\mathrm{U}_{\mathrm{t}}$ - the amount of money invested during the year $\mathrm{t}$ with the interest of annual $\mathrm{p} \%, \mathrm{t}$ $=1,2, \ldots \mathrm{k}$

b) Optimization task

To maximize the function to obtain

$$
\begin{aligned}
& (\max ) Z=\sum_{i=1}^{m} I_{i t}^{j i} X_{i, k+1-j_{i}}\left(1+\frac{q_{i}}{100}\right)+U_{k}\left(1+\frac{p}{100}\right) \text { with limitations } \\
& \sum_{i=1}^{m} X_{i t}+U_{t}=N \\
& X_{i t} \geq N_{i}, i=1,2, \ldots m \\
& \sum_{i=1}^{m} I_{i t}^{j i} X_{i t}+U_{t}=\sum_{i=1}^{m} J_{i t}^{j i} X_{i, t-j i}\left(1+\frac{q_{i}}{100}\right)+U_{t-1}\left(1+\frac{p}{100}\right), \\
& t=1,2, \ldots, k ; U_{o}=0 \\
& X_{i t} \geq 0, i=1,2, \ldots, m ; t=1,2, \ldots, k
\end{aligned}
$$

Where $I_{i t}^{j i}$ and $J_{i t}^{j i}$ variable indicators defined by

$$
\begin{aligned}
& I_{i t}^{j i}=\left\{\frac{0, k+1-t \leq j_{i}}{1, k+1-t \geq j_{i}}\right\}, i=1,2, \ldots, m ; t=1,2, \ldots, k \\
& J_{i t}^{j i}=\left\{\frac{0, t-j_{i} \leq 0}{1, t-j_{i} \geq 0}\right\}, i=1,2, \ldots, m ; t=1,2, \ldots, k
\end{aligned}
$$


The model can be easily extended to other limitations relating to investments for the establishment of certain clones.

Determination of sugar content in the grape must is performed to assess the quality and determine the time of the grape harvest. The tested clones were suitable for the production of quality wines. In clones of the variety Cabernet sauvignon, as expected, a relatively high sugar content in all categories of clusters of different positions on the bearing shoot was expressed (Table 5). It can be said that in this respect, the clone ISV-F-V6 was in forefront compared to other clones. The total amount of sugar varies depending on the weather conditions during the ripening of grapes, cultural practices/ applied agro-technical practices, or it may be an indicator of adaptability of the variety to the given locality.

The total acid content was unusually high (above $10.0 \mathrm{~g} / \mathrm{l}$ ) which can be justified by somewhat earlier harvest considering that the individual vines were located in the production orchard where the harvest is non-selective. The amount of acids in grape must ranges usually between 6.5 and $8.5 \mathrm{~g} / \mathrm{l}$ and in wine between 4 and $8 \mathrm{~g} / \mathrm{l}$ as a part of the acid precipitates in the form of salts during alcoholic fermentation.

Table 5. Average content of sugar and total acids in grape must

\begin{tabular}{|c|c|c|c|c|c|c|}
\hline \multirow{2}{*}{ Clone } & \multicolumn{2}{|c|}{ Sugar content in the grape must (\%) } & \multicolumn{3}{|c|}{ Total acid content (\%) } \\
\cline { 2 - 7 } & base & middle & top & base & middle & top \\
\hline ISV-F-V5 & 24.4 & 23.0 & 21.7 & 11.2 & 11.6 & 12.0 \\
\hline ISV-F-V6 & 25.1 & 24.4 & 21.7 & 10.0 & 10.8 & 10.8 \\
\hline R5 & 23.3 & 21.7 & 19.6 & 10.8 & 11.2 & 12.0 \\
\hline
\end{tabular}

In all clones the same tendencies were demonstrated. Grape clusters in the base of bearing shoots had the highest sugar content and the lowest total acids, while grape clusters at the highest position, which are otherwise later formed, had the lowest total sugars and the highest total acids content. This confirms the fact that the clusters according to their position on the bearing shoot adversely affect the quality of the grapes and their contribution in the total yield is very low, and therefore should be removed in order to improve the quality of grapes.

The quality and yield of wine depends on the quality and yield of grape must. For $1 \mathrm{hl}$ of grape must an average of 125-135 kg of grapes is necessary, and for $1 \mathrm{hl}$ wine $130-150 \mathrm{~kg}$ of grapes. Of the total amount of grape must, $60 \%$ is separated as free-run, $30 \%$ as the first press fraction and about $10 \%$ as the second press fraction. Free-runis the fraction of the highest quality (the highest sugar and acid contents) while the press fraction sare richer in extractive substances. In the practice usually free-run is mixed with press factions in a ratio which should ensure the production of the highest quality wines.

Due to market demands the biggest problem for the manufacturers is how to maintain the standard quality of wines. For this purpose, it is sometimes necessary to correct/modify the chemical composition of the grape must (more often the sugar content is corrected/modified 
than acid). Legal regulations determine/stipulate the level of correction/modification that must be controlled and monitored by the respective institutions.

\section{Conclusion}

Based on the performed tests and the results obtained it was revealed that the clone IS-F-V6 stood out in regard to the potential yield capacity. Clone ISV-F-V6 exhibited the best quality characteristics and it can be safely said that it was the best among the tested clones. In all clones the same tendencies were demonstrated in regard to size and quality of grape clusters of different positions on the bearing shoot. The first grape clusters in the base of bearing shoot were the most, they had the highest average mass, and therefore their share in the total yield was the highest. In addition, they resulted in the grape must of the best quality. Grape clusters on top of bearing shoots (third position starting from the base) had the lowest mass and significantly lower quality. In order to improve the quality of grapes and grape products, especially wine, these grapes should be removed. The tested clones were adapted to site conditions and are recommended for further expansion in the region of Grocka vineyards. Best production results were achieved by growing clones ISV-F-V6.

\section{References}

1. Avramov, L., Žunić, D. (2001): Posebno vinogradarstvo, Poljoprivredni fakultet, Beograd.

2. Cindrić, P., Korać, N., Kovač, V. (2000): Sorte vinove loze-metode i rezultati ispitivanja, Prometej, Novi Sad.

3. Golino, D., Wolpert, J., Sim, S., Benz, J., Anderson, M., Rowhani, A. (2008): Virus effects on vine and fruit components of three California, ,heritage " clones of Cabernet sauvignon, Proceedings of the $2^{\text {nd }}$ Annual National Viticulture Research Conference, July 9-11, University of California, Davis, USA.

4. Milosavljević, M. (1998): Biotehnologija vinove loze, Draganić, Beograd.

5. Nakalamić, A., Marković, N. (2009): Opšte vinogradarstvo, Poljoprivredni fakultet, Beograd.

6. Prostoserdov, N. (1946): Tehnologičeskae harakteristike vinograda i produktiv ego pererabotki, Ampelografia SSSR, Moskva.

7. Rühl, E. H., Konrad, B., Lindner, B., Bleser, E. (2004): Quality Criteria and Targets

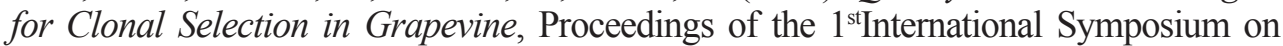
Grapevine Growing, Commerce and Research, ISHS, Belgium, Acta Horticulturae, $\mathrm{N}^{\mathrm{o}}$ 652, pp. 29-33.

8. Žunić, D. (2009): Atlas sorti vinove loze, Centar za vinogradarstvo i vinarstvo, Niš. 


\title{
UTICAJ RAZLIČITOG POLOŽAJA GROZDOVA NA RODNOM LASTARU NA REZULTATE PROIZVODNJEKLONOVA SORTE KABERNE SOVINJON
}

\author{
Ana Čoloveićc ${ }^{6}$ Dragoljub Žunič ${ }^{7}$, Ivana Ljubanović Ralević ${ }^{8}$, \\ Branka Kalanović Bulatović9 ${ }^{9}$ Mirjana Lukač Bulatović ${ }^{10}$
}

\begin{abstract}
Rezime
U radu su utvrđene razlike između klonova sorte Kaberne Sovinjon, odnosno razlike između uvoloških svojstava grozda i bobice, na osnovu različitog položaja na lastaru. Za brojne analize prinosa grožđa, uvoloških svojstava klonova korišćene su standardne ampelografske metode. Svi podaci su statistički obrađeni po metodi dvofaktorske analize varijanse sa ponovljenim merenjima jednog faktora (visine) i Tukey HSD testa. Najbolji rezultati su postignuti kod grozdova u osnovi rodnog lastara. Prvi grozdovi po položaju na lastaru imaju najveće učešće u ukupnom prinosu grožđa, najveću količinu šećera, a najviši grozdovi imaju veći sadržaj ukupnih kiselina. Između ispitivanih klonova su utvrđene razlike u pogledu produktivnosti i kvaliteta grozdova što se odrazilo i na vrednost proizvodnje.
\end{abstract}

Ključne reči: Kaberne sovinjon, klonovi, položaj lastara, uvološka svojstva grozda, rezultati proizvodnje.

6 Ana M. Čoloveić, dipl. inž., Univerzitet u Beogradu, Poljoprivredni fakultet, Nemanjina 6, 11080 Beograd, Srbija, Telefon: +381 64 2548993, E-mail: coloveic@gmail.com

7 Dragoljub M.Žunić, redovni profesor, Univerzitet u Beogradu, Poljoprivredni fakultet, Nemanjina 6, 11080 Beograd, Srbija, Telefon: +381 65 5222434, E-mail: dragoljubzunic@gmail.com

8 Ivana I. Ljubanović Ralević, redovni profesor, Univerzitet u Beogradu, Poljoprivredni fakultet, Nemanjina 6, 11080 Beograd, Srbija, Telefon: +381 64 1447496, E-mail: iralevic@agrif.bg.ac.rs

9 Branka M. Kalanović Bulatović, vanredni profesor, Univerzitet u Beogradu, Poljoprivredni fakultet, Nemanjina 6, 11080 Beograd, Srbija, Telefon: +381 64 2743330, E-mail: brankal@agrif.bg.ac.rs

10 Mirjana Ž. Lukač Bulatović, docent, Univerzitet u Novom Sadu, Poljoprivredni fakultet, Trg Dositeja Obradovića 8, 21000 Novi Sad, Srbija, Telefon: +381 63 8929721, E-mail: imirjana@polj.uns.ac.rs 